\title{
Interactions of ovarian steroids with pituitary adenylate cyclase-activating polypeptide and GnRH in anterior pituitary cells
}

\author{
O Ortmann ${ }^{1}$, W Asmus ${ }^{2}$, K Diedrich ${ }^{1}$, K-D Schulz ${ }^{2}$ and G Emons ${ }^{2}$ \\ ${ }^{1}$ Department of Obstetrics and Gynecology, Medical University of Lübeck, Lübeck, Germany and ${ }^{2}$ Department of Obstetrics and Gynecology, \\ Philipps-University Marburg, Marburg, Germany
}

(Correspondence should be addressed to O Ortmann, Department of Obstetrics and Gynecology, Medical University of Lübeck, Ratzeburger Allee 160, 23538 Lübeck, Germany)

\begin{abstract}
Pituitary adenylate cyclase-activating polypeptide (PACAP) releases LH and FSH from anterior pituitary cells. Although this effect is relatively weak, it has a strong sensitizing action on GnRHinduced gonadotropin secretion. Here we investigated the possibility that ovarian steroids, which are well-known modulators of LH secretion, interact with PACAP and GnRH in pituitary gonadotrophs. Rat pituitary cells were treated for $48 \mathrm{~h}$ with vehicle, $1 \mathrm{nmol} / \mathrm{l}$ estradiol, $1 \mathrm{nmol} / \mathrm{l}$ estradiol $+100 \mathrm{nmol} / \mathrm{l}$ progesterone or $48 \mathrm{~h}$ with $1 \mathrm{nmol} / \mathrm{l}$ estradiol and $4 \mathrm{~h}$ with $100 \mathrm{nmol} / \mathrm{l}$ progesterone. The cells were stimulated for $3 \mathrm{~h}$ with $1 \mathrm{nmol} / \mathrm{l} \mathrm{GnRH}$ or $100 \mathrm{nmol} / \mathrm{l}$ PACAP. Estradiol treatment alone enhanced basal as well as GnRH- or PACAP-stimulated LH secretion. LH release was facilitated by additional short-term progesterone treatment. Long-term treatment with estradiol and progesterone led to reduced LH responses to GnRH and PACAP. Neither treatment paradigms affected cAMP production. However, estradiol treatment led to enhanced cAMP accumulation in quiescent or GnRH-stimulated cells. PACAP-induced increases of cAMP production were inhibited by estradiol treatment.

After 7 -h preincubation with $10 \mathrm{nmol} / \mathrm{l}$ PACAP, cells responded with enhanced $\mathrm{LH}$ secretion to $\mathrm{GnRH}$ stimulation. When steroid pretreatment was performed the responsiveness of gonadotrophs to low concentrations of GnRH was still increased. In contrast, at high concentrations of GnRH the sensitizing action of PACAP on agonist-induced LH secretion was lost in steroid-treated cells. There were no significant differences between the steroid treatment paradigms.

It is concluded that estradiol but not progesterone acts as a modulator of adenylyl cyclase in gonadotrophs. The stimulatory effect of estradiol is thought to be involved in its sensitizing action on agonist-induced LH secretion. The inhibitory effect of estradiol on PACAP-stimulated adenylyl cyclase activities seems to be responsible for the loss of its action to sensitize LH secretory responses to GnRH.
\end{abstract}

European Journal of Endocrinology 140 207-214

\section{Introduction}

Pituitary adenylate cyclase-activating polypeptide (PACAP) was isolated from hypothalamic tissue by its ability to stimulate cAMP production in anterior pituitary cells (1). Two isoforms with 38 (PACAP 38) and 27 (PACAP 27) amino acid residues have been identified (2). The major isoform, PACAP 38, is found predominantly in the hypothalamus $(3,4)$. Although the physiological role of PACAP has not yet been clarified, it may act as a hypophysiotropic hormone. It has been shown to release a number of hormones including luteinizing hormone (LH) and folliclestimulating hormone (FSH) from anterior pituitary cells $(1,5,6)$. Although its potency to release both gonadotropins is relatively low, it has a strong sensitizing effect on gonadotropin-releasing hormone (GnRH)induced LH secretion $(6,7)$. This ability of PACAP might be due to its stimulatory action on the cAMP-protein kinase A pathway in gonadotrophs since cAMP analogs and adenylyl cyclase activators enhance GnRHstimulated LH secretion (8-10). If PACAP serves as a modulator of gonadotropin secretion it might interact with other hormones which are well-known modulators of gonadotropin secretion, such as ovarian steroids. Estradiol has a sensitizing effect on GnRH-induced $\mathrm{LH}$ secretion which is facilitated by progesterone (11-13). These steroid actions are essential for the initiation of the preovulatory LH surge (14). The prolonged exposure of the pituitary to progesterone in the luteal phase leads to suppressed gonadotropin secretion $(15,16)$. The combined actions of PACAP and gonadal steroids could be of physiological relevance for the cyclic regulation of gonadotropin secretion. In the present paper we examined the effects of PACAP 38, estradiol, progesterone and combinations of these hormones on 
GnRH-stimulated LH secretion and cAMP production in cultured rat pituitary cells. These studies provide further information on the role of PACAP for gonadotropin secretion and steroid actions on adenylyl cyclase.

\section{Materials and methods}

\section{Pituitary cell preparation and culture conditions}

Pituitary glands obtained from adult female Wistar rats (Winkelmann, Borchen-Kirchborchen, Germany) at random stages of the estrous cycle were dispersed into single cells by controlled trypsinization as described previously (17). Dispersed pituitary cells were cultured in phenol red-free medium-199 (Biochrom, Berlin, Germany) containing Hank's salts supplemented with $1.4 \%$ sodium bicarbonate. $10 \%$ horse serum that had been pretreated with $2 \%$ charcoal (Norit A) and $0.2 \%$ Dextran T70 (Pharmacia, Uppsala, Sweden), $10 \mu \mathrm{g} / \mathrm{ml}$ streptomycin and $100 \mathrm{U} / \mathrm{l}$ penicillin at $37^{\circ} \mathrm{C}$ under $5 \%$ $\mathrm{CO}_{2}$ /air and saturated humidity. Cells were grown on multiwell culture dishes $(200000$ cells/well $)$ and allowed to attach for $36-48 \mathrm{~h}$ before experiments were started. GnRH (Sigma, Deisenhofen, Germany) and PACAP 38 (Saxon, Hannover, Germany) were dissolved in phosphate-buffered serum (PBS) containing $0.1 \%$ bovine serum albumin. Stock solutions of estradiol and progesterone (Sigma) were prepared in ethanol. The final concentration of ethanol in the culture media was $0.2 \%$.

\section{Effects of estradiol, progesterone and PACAP 38 on basal and GnRH-induced LH secretion and $\mathrm{cAMP}$ release}

In order to determine the effects of ovarian steroids on GnRH- and PACAP-stimulated LH secretion and cAMP release, pituitary cells were incubated for $48 \mathrm{~h}$ with vehicle $(0.2 \%$ ethanol $), 1 \mathrm{nmol} / \mathrm{l}$ estradiol, $1 \mathrm{nmol} / \mathrm{l}$ estradiol $+100 \mathrm{nmol} / \mathrm{l}$ progesterone or pretreated for $48 \mathrm{~h}$ with $1 \mathrm{nmol} / \mathrm{l}$ estradiol and then treated for $4 \mathrm{~h}$ with $100 \mathrm{nmol} / \mathrm{l}$ progesterone. During the last $3 \mathrm{~h}$ of these treatment periods cells were incubated with or without $1 \mathrm{nmol} / \mathrm{l} \mathrm{GnRH}$ or $100 \mathrm{nmol} / \mathrm{l} \mathrm{PACAP} 38$. Media were collected and analyzed for LH and cAMP.

\section{Effects of PACAP on GnRH-induced LH secretion from steroid-treated cells}

To test the effect of PACAP 38 on GnRH-induced LH secretion, pituitary cells were treated for $7 \mathrm{~h}$ with PACAP 38 and then stimulated with increasing concentrations of GnRH $\left(0,10^{-11}\right.$ to $\left.10^{-6} \mathrm{~mol} / \mathrm{l}\right)$. To elucidate the interactions of estradiol, progesterone and PACAP on GnRH-stimulated LH release, cells were incubated for $48 \mathrm{~h}$ with vehicle, $1 \mathrm{nmol} / \mathrm{l}$ estradiol,
$1 \mathrm{nmol} / \mathrm{l}$ estradiol+100 nmol/l progesterone or pretreated for $48 \mathrm{~h}$ with $1 \mathrm{nmol} / \mathrm{l}$ estradiol and then treated for $4 \mathrm{~h}$ with $100 \mathrm{nmol} / \mathrm{l}$ progesterone. During the last $7 \mathrm{~h}$ the cells were incubated with or without $10 \mathrm{nmol} / \mathrm{l}$ PACAP. Then the cells were stimulated for $3 \mathrm{~h}$ with increasing concentrations of $\mathrm{GnRH}\left(0,10^{-11}\right.$ to $10^{-6}$ $\mathrm{mol} / \mathrm{l})$. At the end of the stimulation periods with $\mathrm{GnRH}$ media were collected and analyzed for $\mathrm{LH}$.

\section{Radioimmunoassay and data analysis}

The LH content of the samples was determined by radioimmunoassay, using the reference preparation RP3 rat LH provided by the National Hormone and Pituitary Program (Rockville, MD, USA). The sensitivity of the assay was $312 \mathrm{ng} / \mathrm{ml}$, the intra- and interassay variabilities were less than $10 \%$. LH was expressed in $\mathrm{ng} / \mathrm{ml}$ culture medium or in per cent of the LH release from vehicle-treated cells. The amount of cAMP in the media was determined by scintillation proximity assay (Biotrak SPA, Amersham International plc, Amersham, Bucks, UK). The sensitivity of the assay was $7 \mathrm{pg} / \mathrm{ml}$, the intra- and interassay variabilities were less than 9\%. The data are expressed in per cent of control (no PACAP, steroids or GnRH). All experiments were performed in triplicate and repeated three times. Statistically significant differences between treatments were determined by analysis of variance followed by a Newman-Keuls test using the InStat program (Graph Pad software, San Diego, CA, USA); $P<0.05$ was considered to be statistically significant. Dose-response curves were compared by the Allfit program (18).

\section{Results}

\section{Effects of estradiol, progesterone and PACAP 38 on basal and GnRH-induced LH secretion and cAMP release}

Long-term (48 h) treatment of pituitary cells with $1 \mathrm{nmol} / \mathrm{l}$ estradiol led to about twofold increases of basal LH release. This action was slightly enhanced by additional 4-h progesterone treatment while long-term treatment with estradiol and progesterone reversed the increase of LH release observed in estradiol-treated cells (Fig. 1). The release of cAMP into the culture medium was enhanced nearly threefold by estradiol treatment. This action was not influenced by additional progesterone treatment (Fig. 1). GnRH-induced LH secretion from pituitary cells was increased by 48 -h estradiol incubation. This effect of estradiol was facilitated by the short-term progesterone treatment paradigm. The combined treatment with estradiol and progesterone led to reduced LH responses when compared with estradiol treatment alone (Fig. 2).

The modulatory actions of estradiol and progesterone on PACAP-stimulated LH secretion were similar (Fig. 3). 

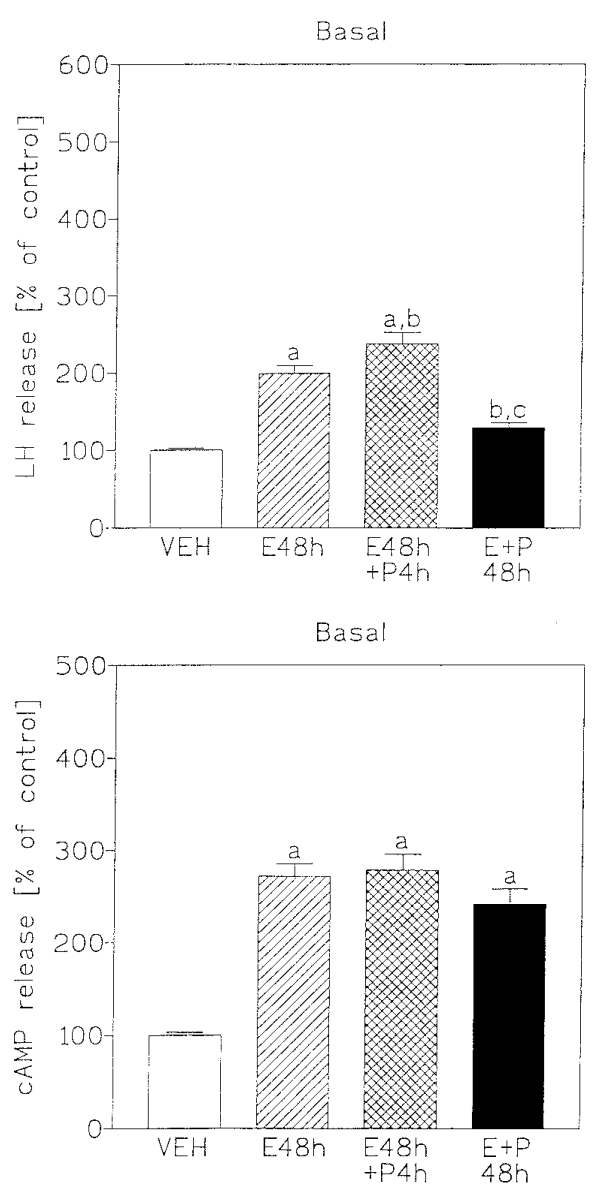

Figure 1 Effects of estradiol $(E)$ and progesterone $(P)$ on basal (upper) LH and (lower) cAMP release from cultured rat pituitary cells. Cells were treated for $48 \mathrm{~h}$ with vehicle (VEH; $0.2 \%$ ethanol), $1 \mathrm{nmol} / \mathrm{I} \mathrm{E}, 1 \mathrm{nmol} / / \mathrm{E}+100 \mathrm{nmol} / \mathrm{P}$ or for $48 \mathrm{~h}$ with $1 \mathrm{nmol} / \mathrm{l} \mathrm{E}$ and a further $4 \mathrm{~h}$ with $100 \mathrm{nmol} / \mathrm{l} \mathrm{P}$. LH and cAMP were determined in the culture media at the end of the treatments during a 3-h period after washing the cells. Data are presented as the percentage (mean \pm S.E.) of LH or CAMP secretion in VEH-treated cells $(=100 \%)$. a, $P<0.05$ vs VEH; $b, P<0.05$ vs $E$.

PACAP itself led to a twofold stimulation of LH release. However, the magnitude of the sensitizing estradiol and progesterone effects was smaller than in GnRH-stimulated cells. GnRH was virtually without an effect on cAMP release (Fig. 2). This was also the case when the cells were incubated for prolonged periods $(6 \mathrm{~h})$ with the decapeptide (data not shown). As in non-stimulated cells, estradiol exerted a threefold increase of cAMP release that was not altered by short- or long-term progesterone treatment (Fig. 2).

PACAP induced a robust stimulatory action on cAMP release with 100-fold increases compared with controls (Fig. 3). In contrast to the action of estradiol in basal and GnRH-stimulated cAMP release, estradiol reduced the cAMP response to PACAP by about 50\% (Fig. 3). Again, progesterone was without any action when compared with the effect of estradiol alone.
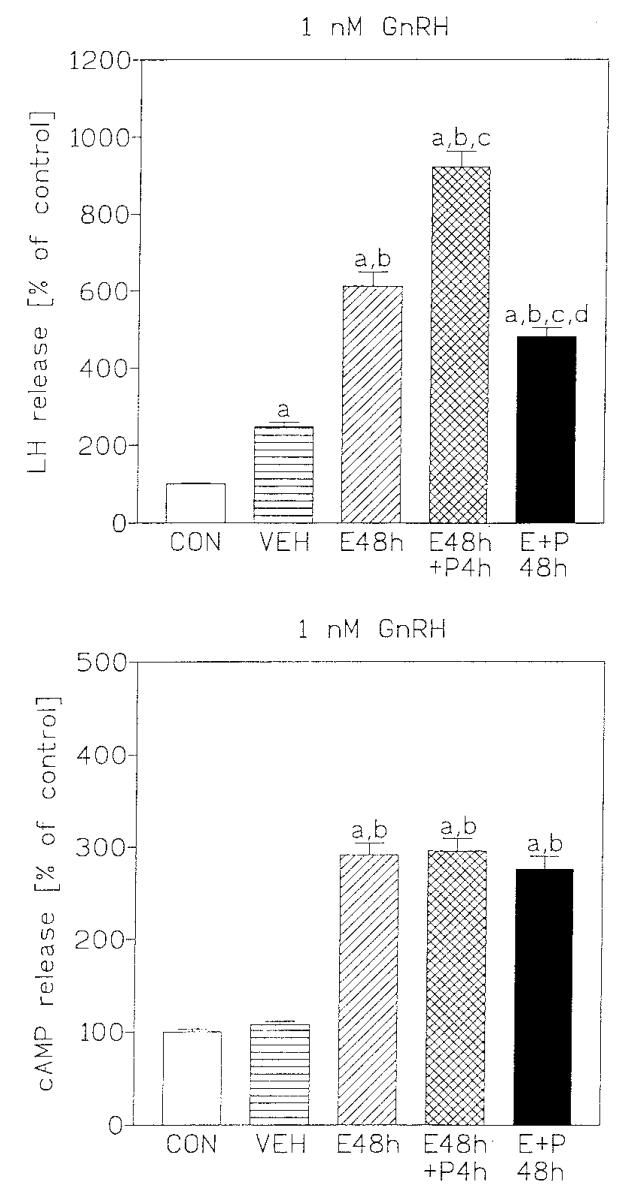

Figure 2 Effects of estradiol $(E)$ and progesterone $(P)$ on $\mathrm{GnRH}$ stimulated (upper) LH and (lower) cAMP release from cultured rat pituitary cells. Cells were treated with $E$ and $P$ as described in Fig. 1. $\mathrm{LH}$ and CAMP were determined in the media at the end of a 3-h stimulation period with $1 \mathrm{nmol} / \mathrm{l} \mathrm{nnRH}$. Data are expressed as the percentage (mean \pm S.E.) of controls (CON; $100 \%$; no steroid or GnRH treatments). a, $P<0.05$ vs CON; b, $P<0.05$ vs VEH; , $P<0.05$ vs $\mathrm{E} ; \mathrm{d}, P<0.05$ vs $\mathrm{E} 48 \mathrm{~h}+\mathrm{P} 4 \mathrm{~h}$.

\section{Effects of PACAP 38 on GnRH-induced LH secretion from steroid-treated cells}

The data of the present study confirm our previous observations on steroid actions on GnRH-stimulated LH secretion. Long-term estradiol treatment has a stimulatory action on GnRH-induced LH secretion with enhanced maximal secretory responses and a shift in the $\mathrm{EC}_{50}$ from $5.6 \pm 1.3 \times 10^{-9} \mathrm{~mol} / \mathrm{l}$ to $1.8 \pm 0.6 \times 10^{-9}$ $\mathrm{mol} / \mathrm{l}$ (Fig. 4, Table 1). The additional short-term progesterone incubation led to increased sensitivity $\left(\mathrm{EC}_{50}=4.6 \pm 1.7 \times 10^{-10} \mathrm{~mol} / \mathrm{l}\right)$. Combined treatment with estradiol and progesterone reduced the maximal response to $\mathrm{GnRH}$ and increased the $\mathrm{EC}_{50}$ to $2.0 \pm 0.4 \times 10^{-9} \mathrm{~mol} / \mathrm{l}$ (Fig. 4, Table 1).

When the cells had been pretreated with PACAP a stimulatory action of the polypeptide on LH secretion was observed in the absence of GnRH (Fig. 5, Table 1). 

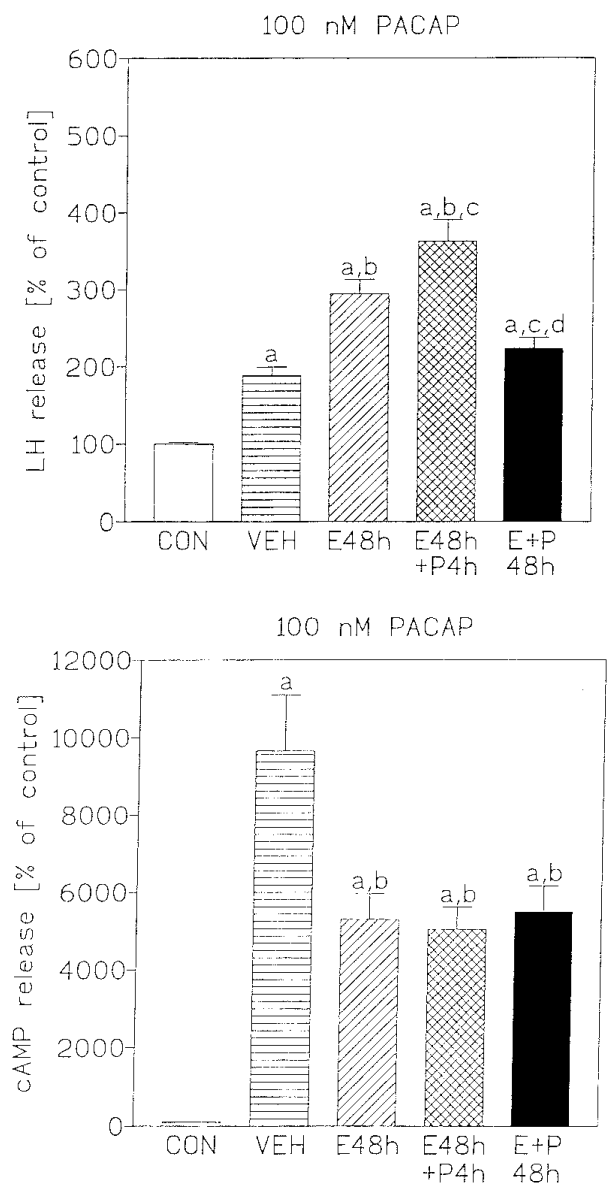

Figure 3 Effects of estradiol $(E)$ and progesterone $(P)$ on PACAP stimulated (upper) LH and (lower) CAMP release from cultured rat pituitary cells. Cells were treated with $E$ and $P$ as described in Fig. 1. $\mathrm{LH}$ and CAMP were determined in the media at the end of a 3-h stimulation period with $100 \mathrm{nmol} / \mathrm{PACAP} 38$. Data are expressed as the percentage (mean \pm S.E.) of controls (CON; $100 \%$; no steroid or PACAP treatments). a, $P<0.05$ vs $C O N ; b, P<0.05$ vs VEH; $c$, $P<0.05$ vs $\mathrm{E} ; \mathrm{d}, P<0.05$ vs $\mathrm{E} 48 \mathrm{~h}+\mathrm{P} 4 \mathrm{~h}$.

Table 1 Effects of estradiol $(E)$ and progesterone $(P)$ on $\mathrm{GnRH}$ stimulated LH secretion in PACAP-pretreated pituitary cells.

\begin{tabular}{|c|c|c|c|}
\hline Treatment & Minimum & $\mathrm{EC}_{50}$ & Maximum \\
\hline $\begin{array}{l}\text { No PACAP pret } \\
\text { Vehicle } \\
\text { E } 48 \mathrm{~h} \\
\text { E } 48 \mathrm{~h}+\mathrm{P} 4 \mathrm{~h} \\
\mathrm{E}+\mathrm{P} 48 \mathrm{~h}\end{array}$ & $\begin{array}{r}\text { eatment } \\
4.5 \pm 0.9 \\
6.5 \pm 2.7 \\
7.2 \pm 3.8 \\
1.85 \pm 1.0\end{array}$ & $\begin{array}{l}5.6 \pm 1.3 \times 10^{-9} \\
1.8 \pm 0.6 \times 10^{-9} \\
4.6 \pm 1.7 \times 10^{-10} \\
2.0 \pm 0.4 \times 10^{-9}\end{array}$ & $\begin{array}{l}38.7 \pm 1.5 \\
75.7 \pm 3.5 \\
75.0 \pm 3.3 \\
43.6 \pm 1.3\end{array}$ \\
\hline $\begin{array}{l}\text { PACAP pretreat } \\
\text { Vehicle } \\
\text { E } 48 \mathrm{~h} \\
\mathrm{E} 48 \mathrm{~h}+\mathrm{P} 4 \mathrm{~h} \\
\mathrm{E}+\mathrm{P} 48 \mathrm{~h}\end{array}$ & $\begin{array}{l}\text { ment } \\
18.8 \pm 1.2^{\mathrm{a}} \\
14.6 \pm 2.7 \\
15.5 \pm 4.0 \\
10.4 \pm 1.2^{\mathrm{a}}\end{array}$ & $\begin{array}{l}2.0 \pm 0.9 \times 10^{-9} \\
5.5 \pm 2.2 \times 10^{-10} \\
3.1 \pm 1.7 \times 10^{-10} \\
1.8 \pm 1.0 \times 10^{-9}\end{array}$ & $\begin{array}{l}41.5 \pm 1.6 \\
59.6 \pm 2.4^{\mathrm{a}} \\
61.3 \pm 3.2^{\mathrm{a}} \\
34.8 \pm 2.0\end{array}$ \\
\hline
\end{tabular}

Analyses of LH dose-response curves by Allfit.

Minimum and maximum values are in $\mathrm{ng} \mathrm{LH} / 200000$ cells per $\mathrm{ml}$. $\mathrm{EC}_{50}$ values are in $\mathrm{mol} / \mathrm{l}$.

a, $P<0.05$ vs the corresponding steroid treatment in cells that were not pretreated with PACAP.
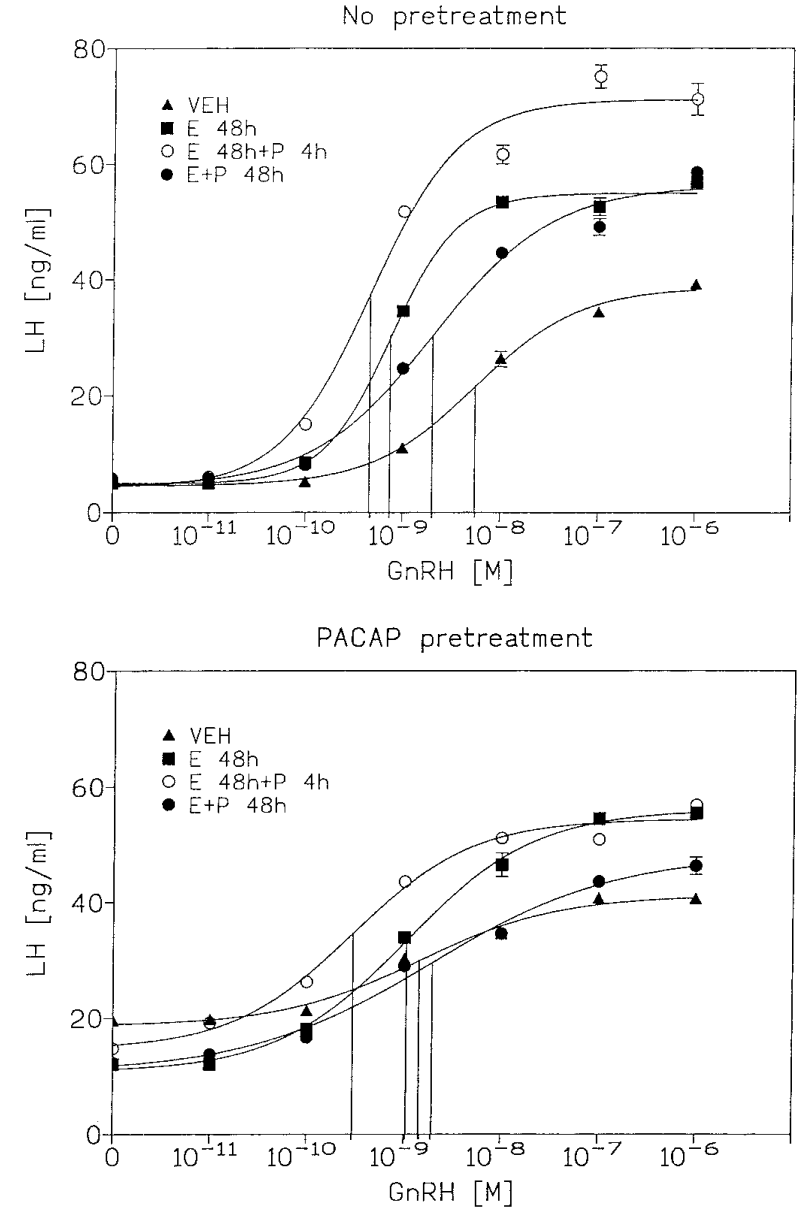

Figure 4 Effects of (upper) no pretreatment and (lower) PACAP pretreatment on sensitizing and desensitizing steroid actions on $\mathrm{GnRH}$-stimulated $\mathrm{LH}$ secretion. Cells were treated with $E$ and $\mathrm{P}$ as described in Fig. 1. Before the 3-h stimulation with $\mathrm{GnRH}$ cells were incubated for $7 \mathrm{~h}$ with or without $10 \mathrm{nmol} / \mathrm{I} \mathrm{PACAP} 38$. Vertical lines indicate $\mathrm{EC}_{50}$ values.

Also, there was a leftward shift in the $\mathrm{EC}_{50}$ in PACAPpretreated GnRH-stimulated cells that did not receive any steroid treatments. The maximal response to GnRH remained unchanged (Fig. 5, Table 1). When we compared the steroid actions on GnRH-stimulated LH secretion from cells that were pretreated with PACAP with those that did not get such pretreatment, there were no significant changes in the $\mathrm{EC}_{50}$ values. However, the maximal response was reduced in PACAP-pretreated cells. Furthermore, there were enhanced responses to low concentrations of $\mathrm{GnRH}$ as observed in cells that had not been pretreated with estradiol or progesterone (Figs 4 and 5).

\section{Discussion}

The findings in the present study show interactions of ovarian steroids with PACAP on LH secretion from 

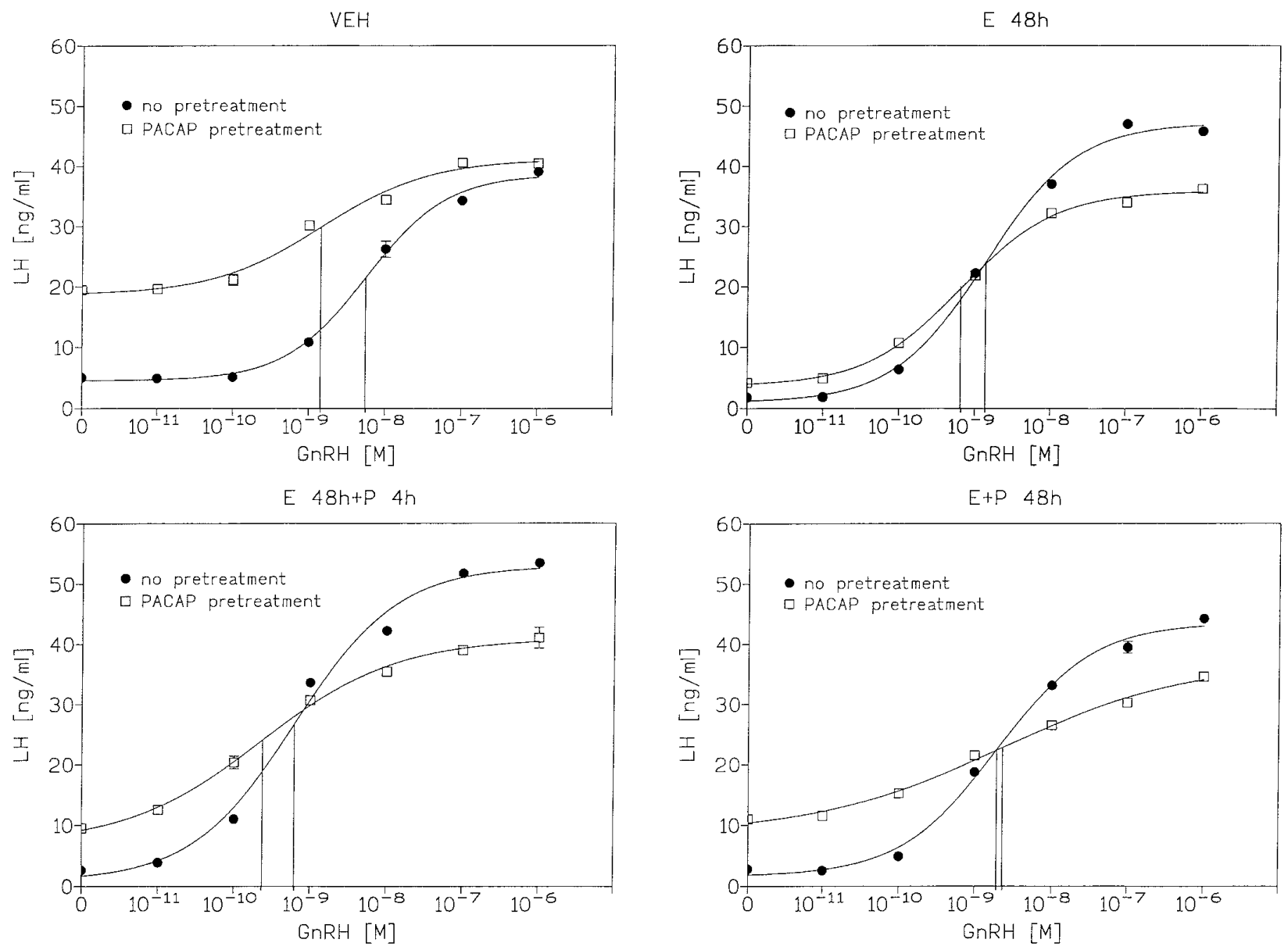

Figure 5 Comparison of dose-response curves to GnRH under different steroid treatment paradigms in the absence or presence of PACAP. Cells were treated with $\mathrm{E}$ and $\mathrm{P}$ as described in Fig. 1. Before the 3-h stimulation with $\mathrm{GnRH}$ cells were incubated for $7 \mathrm{~h}$ with or without $10 \mathrm{nmol} / \mathrm{PACAP} 38$. Vertical lines indicate $\mathrm{EC}_{50}$ values.

pituitary gonadotrophs. Secretory responses of these cells to PACAP are modulated by estradiol and progesterone in a similar manner as in GnRH-stimulated cells. Since GnRH is the primary regulator of $\mathrm{LH}$ and FSH and ovarian steroids serve as the most important modulators which exert the cyclic variations of gonadotropin release we have tested the possibility of whether PACAP could interfere with this process.

Recent studies have demonstrated that PACAP exerts a weak stimulatory action on LH secretion from cultured rat pituitary cells $(1,6,19,20)$. In addition, the polypeptide increases the sensitivity of pituitary gonadotrophs to $\mathrm{GnRH}$, leading to a leftward shift of LH dose-response curves (7). The data of the present study have confirmed these findings. It has been claimed that PACAP might act as a hypophysiotropic factor and influence several functions of gonadotrophs. These include exocytosis of $\mathrm{LH}$ and $\mathrm{FSH}$ as well as gene expression of the gonadotropin subunits $(6,7,21,22)$. Presumably these PACAP actions are mediated via type I receptors which have been shown to be coupled to adenylate cyclase and phospholipase C (22-24). The ability of PACAP to activate the cAMP-protein kinase A pathway is largely responsible for its sensitizing action on GnRH-induced LH secretion (for review see 25). We have shown that this effect is lost at high concentrations of GnRH. This might be due to the inhibitory action of GnRH on PACAP-induced cAMP production.

Furthermore, estradiol has been described as activating the cAMP-protein kinase A pathway. Such activity could influence PACAP and GnRH effects on gonadotroph functions. In the present study, estradiol was found to induce cAMP formation in the absence or presence of GnRH. This steroid effect could partially explain its sensitizing action on LH secretory responses of gonadotrophs as it has been demonstrated that elevation of cAMP in these cells leads to increased sensitivity to $\operatorname{GnRH}(8,26)$. Other mechanisms such as $\mathrm{GnRH}$ receptor regulation are certainly involved (2729). 
Progesterone did not affect the increases of cAMP production that have been observed after estradiol incubation either in the short-term or in the long-term treatment paradigm. This finding demonstrates that progesterone modulation of GnRH-induced LH secretion does not involve a cAMP-dependent mechanism. Recent studies from our group have shown that progesterone exerts its inhibitory and stimulatory effects on gonadotropin secretion by acting on GnRH receptors and different pathways of GnRH signal transduction (3034). In particular, the ability of progesterone to act as a bidirectional regulator of agonist-induced $\mathrm{Ca}^{2+}$ signals in gonadotrophs seems to be important for the modulation of secretory responses of these cells (31, 35). When PACAP was used to stimulate LH secretion from cultured rat pituitary cells that had been exposed to the different steroid treatment paradigms we observed the same modulatory actions of estradiol and progesterone as in GnRH-stimulated cells. Since PACAP activates phospholipase $\mathrm{C}$ leading to inositol phosphate production and increases of free intracellular $\mathrm{Ca}^{2+}$ concentrations it seems to be likely that the steroids act on this pathway to induce the observed changes of secretory responses to the polypeptide. In accordance with this possibility, we have previously described that estradiol and progesterone modulate LH secretion from gonadotrophs in response to other agonists that activate phospholipase $C$ such as endothelin (36). The fact that gonadal steroids exert stimulatory and inhibitory actions on PACAP-stimulated LH release might explain the controversial data of in vivo studies on the ability of PACAP to induce gonadotropin secretion (19, 37-39).

The robust action of PACAP on cAMP formation was inhibited by 48 -h estradiol treatment by about $50 \%$. This is in contrast to the stimulatory action of estradiol alone or in the presence of GnRH on cAMP production. The addition of progesterone did not alter the inhibitory effect of estradiol, indicating the lack of progesterone action on adenylyl cyclase. The inhibition of PACAPstimulated cAMP production by estradiol might interfere with the action of the polypeptide on gonadotropin secretion. However, pretreatment of pituitary cells with estradiol did enhance but not inhibit the LH secretory response to PACAP. Thus the augmenting action of estradiol on PACAP-stimulated LH secretion seems to be mediated by influences on phospholipase C-dependent signal transduction. Such mechanisms might also be involved in the regulation of progesterone effects on PACAP-induced gonadotropin secretion since this steroid does not influence adenylyl cyclase activity.

If PACAP acts as a physiological regulator of gonadotropin secretion its role as a modulator may be more important than its ability to act as a releasing hormone. Therefore, we investigated the combined actions of ovarian steroids, which are well-characterized modulators of gonadotropin secretion, PACAP and GnRH in gonadotrophs. We assumed that PACAP might interfere with the established inhibitory and stimulatory effects of estradiol and progesterone on GnRH-stimulated LH secretion. Therefore, in addition to the previously tested steroid treatment paradigms, we introduced a 7-h PACAP incubation. Interestingly, at lower concentrations of GnRH the augmenting effect of PACAP on LH secretion was observed independently of the additional estradiol or progesterone treatment. However, at higher concentrations of GnRH, LH secretion was reduced by estradiol incubation. This effect was also present when progesterone was added to the culture media. The stimulating effect of PACAP at lower concentrations of GnRH might be due to its combined action on adenylyl cyclase which leads to sensitization of gonadotrophs and its ability to induce gonadotropin secretion via activation of phospholipase $\mathrm{C}$. The latter effect seems to be more important at lower concentrations of GnRH. At higher concentrations of GnRH, the effect of PACAP to increase cAMP formation leads to enhanced LH responses which are lost at maximal doses of GnRH in cells that were not treated with steroids. However, estradiol which has been shown to inhibit PACAP-induced cAMP production in this study, also inhibits GnRH-stimulated LH secretion from PACAPpretreated cells. Thus the sensitizing effect of PACAP on pituitary gonadotrophs is influenced by estradiol depending on the concentration of GnRH: at low concentrations there is no alteration of the PACAP action, at intermediate concentration the sensitizing effect is lost and at high concentrations the presence of PACAP is inhibitory.

In conclusion, estradiol but not progesterone acts as a modulator of adenylyl cyclase in gonadotrophs. In quiescent cells it increases cAMP formation while it is an inhibitor of PACAP-induced activation of adenylyl cyclase. The former effect is at least in part involved in its sensitizing action on agonist-stimulated LH secretion. The latter seems to be responsible for the loss of the PACAP action to sensitize LH secretory responses to GnRH. The influence of the steroid milieu on PACAP effects in gonadotrophs indicates that PACAP might act differentially during female reproductive cycles. The exact role for the regulation of gonadotropin secretion remains to be determined.

\section{Acknowledgements}

This study was supported by grants from the Deutsche Forschungsgemeinschaft (Or 52/4-3) and the Stiftung PE Kempkes, Marburg, Germany. We are grateful to the National Hormone and Pituitary Program, Rockville, $\mathrm{MD}$, USA for providing the $\mathrm{LH}$ radioimmunoassay reagents.

\section{References}

1 Miyata A, Arimura A, Dahl RR, Minamino N, Uehara A, Jiang L et al. Isolation of a novel 38 residue-hypothalamic polypeptide which stimulates adenylate cyclase in pituitary cells. Biochemical and Biophysical Research Communications 1989164 567-574. 
2 Miyata A, Jiang L, Dahl RD, Kitada C, Kubo K, Fujino M et al. Isolation of a neuropeptide corresponding to the N-terminal 27 residues of the pituitary adenylate cyclase activating polypeptide with 38 residues (PACAP38). Biochemical and Biophysical Research Communications 1990170 643-648.

3 Arimura A, Somogyvari Vigh A, Miyata A, Mizuno K, Coy DH \& Kitada C. Tissue distribution of PACAP as determined by RIA highly abundant in the rat brain and testes. Endocrinology 1991 $1292787-2789$

4 Gottschall PE, Tatsuno I, Miyata A \& Arimura A. Characterization and distribution of binding sites for the hypothalamic peptide. pituitary adenylate cyclase-activating polypeptide. Endocrinology $1990127272-277$.

5 Goth MI, Lyons CE, Canny BJ \& Thorner MO. Pituitary adenylate activating polypeptide, growth hormone $(\mathrm{GH})$-releasing peptide and GH-releasing hormone stimulate $\mathrm{GH}$ release through distinct pituitary receptors. Endocrinology 1992130 939-944.

6 Culler MD \& Paschall CS. Pituitary adenylate cyclase-activating polypeptide (PACAP) potentiates the gonadotropin-releasing activity of luteinizing hormone-releasing hormone. Endocrinology $19911292260-2262$.

7 Tsujii T, Ishizaka K \& Winters SJ. Effects of pituitary adenylate cyclase-activating polypeptide on gonadotropin secretion and subunit messenger ribonucleic acids in perifused rat pituitary cells. Endocrinology $1994135826-833$.

8 Turgeon JL \& Waring DW. cAMP augmentation of secretagogueinduced luteinizing hormone secretion. American Journal of Physiology 1986250 E62-E68.

9 Liu TC, Wang PS \& Jackson GL. Effects of GnRH and drugs that affect cAMP levels on LH synthesis and release. American Journal of Physiology 1981241 E14-E21.

10 Liu TC \& Jackson GL. Differential effects of cyclic nucleotide analogues and GnRH on LH synthesis and release. American Journal of Physiology 1981241 E6-E13.

11 Lagace L, Massicotte J \& Labrie F. Acute stimulatory effects of progesterone on luteinizing hormone and follicle-stimulating hormone release in rat anterior pituitary cells in culture. Endocrinology 1980106 684-689.

12 Turgeon JL \& Waring DW. Rapid augmentation by progesterone of agonist-stimulated luteinizing hormone secretion by cultured pituitary cells. Endocrinology 1990127 773-780.

13 Ortmann O, Wiese H, Knuppen R \& Emons G. Acute facilitory action of progesterone on gonadotropin secretion of perifused rat pituitary cells. Acta Endocrinologica 1989121 426-434.

14 Mahesh VB \& Muldoon TG. Integration of the effects of oestradiol and progesterone in the modulation of gonadotrophin secretion. Journal of Steroid Biochemistry and Molecular Biology 198727 665-675.

15 Drouin J \& Labrie F. Interactions between 17 beta-estradiol and progesterone in the control of luteinizing hormone and folliclestimulating hormone release in rat anterior pituitary cells in culture. Endocrinology 1981108 52-57.

16 Ortmann O, Emons G, Knuppen R \& Catt KJ. Inhibitory effects of the antiprogestin, RU 486, on progesterone actions and luteinizing hormone secretion in pituitary gonadotrophs. Journal of Steroid Biochemistry and Molecular Biology 198932 291-297.

17 Ortmann O, Sturm R, Knuppen R \& Emons G. Weak estrogenic activity of phenol red in the pituitary gonadotroph: re-evaluation of estrogen and antiestrogen effects. Journal of Steroid Biochemistry and Molecular Biology 199035 17-22.

18 DeLean A, Munson PJ \& Rodbard D. Simultaneous analysis of families of sigmoidal curves: application to bioassay, radioligand assay, and physiological dose-response curves. American Journal of Physiology 1978235 E97-E102.

19 Leonhardt S, Jarry H, Kreipe A, Werstler K \& Wuttke W. Pituitary adenylate cyclase-activating polypeptide (PACAP) stimulates pituitary hormone release in male rats. Neuroendocrinology Letters $199214319-328$.

20 Hart GR, Gowing H \& Burrin JM. Effects of a novel hypothalamic peptide, pituitary adenylate cyclase-activating polypeptide, on pituitary hormone release in rats. Journal of Endocrinology 1992 134 33-41.

21 Perrin D, Soling HD, Wuttke W \& Jarry H. The stimulatory effect of pituitary adenylate cyclase activating polypeptide (PACAP) on LH release from rat pituitary cells in vitro does not involve calcium mobilization. Experimental and Clinical Endocrinology 1993101 290-296.

22 Schomerus E, Poch A, Bunting R, Mason WT \& McArdle CA. Effects of pituitary adenylate cyclase-activating polypeptide in the pituitary: activation of two signal transduction pathways in the gonadotrope-derived alpha T3-1 cell line. Endocrinology 1994 134 315-323.

23 Pisegna JR \& Wank SA. Molecular cloning and functional expression of the pituitary adenylate cyclase-activating polypeptide type I receptor. Proceedings of the National Academy of Sciences of the USA $1993906345-6349$.

24 Rawlings SR, Piuz I, Schlegel W, Bockaert J \& Journot L. Differential expression of pituitary adenylate cyclase-activating polypeptide/vasoactive intestinal polypeptide receptor subtypes in clonal pituitary somatotrophs and gonadotrophs. Endocrinology $19951362088-2098$.

25 Rawlings SR \& Hezareh M. Pituitary adenylate cyclase-activating polypeptide (PACAP) and PACAP/vasoactive intestinal polypeptide receptors: actions on the anterior pituitary gland. Endocrine Reviews $1996174-29$.

26 Tang LK \& Spies HG. Effects of gonadal steroids on the basal and LRF-induced gonadotropin secretion by cultures of rat pituitary. Endocrinology $197596349-355$.

27 Menon M, Peegel H \& Katta V. Estradiol potentiation of gonadotropin-releasing hormone responsiveness in the anterior pituitary is mediated by an increase in gonadotropin-releasing hormone receptors. American Journal of Obstetrics and Gynecology $1985151534-540$.

28 Clayton RN. Gonadotrophin-releasing hormone: its actions and receptors. Journal of Endocrinology 1989120 11-19.

29 Emons G, Hoffmann HG, Brack C, Ortmann O, Sturm R, Ball P et al. Modulation of gonadotropin-releasing hormone receptor concentration in cultured female rat pituitary cells by estradiol treatment. Journal of Steroid Biochemistry and Molecular Biology $198831751-756$.

30 Emons G, Nill J, Sturm R \& Ortmann O. Effects of progesterone on gonadotropin-releasing hormone receptor concentration in cultured estrogen-primed female rat pituitary cells. Journal of Steroid Biochemistry and Molecular Biology 199242 831-839.

31 Ortmann O, Stojilkovic SS, Cesnjaj M, Emons G \& Catt KJ. Modulation of cytoplasmic calcium signaling in rat pituitary gonadotrophs by estradiol and progesterone. Endocrinology 1992 131 1565-1567.

32 Ortmann O, Bakhit M, Bloh P, Schulz KD \& Emons G. Ovarian steroids modulate gonadotropin-releasing hormone-induced biphasic luteinizing hormone secretory responses and inositol phosphate accumulation in rat anterior pituitary cells and alpha T3-1 gonadotrophs. Journal of Steroid Biochemistry and Molecular Biology 199554 101-109.

33 Ortmann O, Tilse B \& Emons G. Modulatory actions of estradiol and progesterone on phorbol ester-stimulated LH secretion from cultured rat pituitary cells. Journal of Steroid Biochemistry and Molecular Biology 199243 619-627.

34 Ortmann O, Ansari-Pirsarai B, Bloh P, Schulz KD \& Emons G. Modulatory actions of progesterone on gonadotropin-releasing hormone-induced arachidonic acid liberation from perifused rat pituitary cells. European Journal of Endocrinology 1996135 626630.

35 Ortmann O, Merelli F, Stojilkovic SS, Schulz KD, Emons G \& Catt KJ. Modulation of calcium signaling and LH secretion by progesterone in pituitary gonadotrophs and clonal pituitary cells. Journal of Steroid Biochemistry and Molecular Biology 1994 48 47-54.

36 Ortmann O, Wassmann D, Stojilkovic SS, Catt KJ, Schulz KD \& Emons G. Ovarian steroids modulate endothelin-induced 
luteinizing hormone secretion from cultured rat pituitary cells. Endocrinology $19931332632-2638$.

37 Hammond PJ, Talbot K, Chapman R, Ghatei MA \& Bloom SR. Vasoactive intestinal peptide, but not pituitary adenylate cyclaseactivating peptide, modulates the responsiveness of the gonadotroph to LHRH in man. Journal of Endocrinology 1993 137 529-532.

38 Osuga Y, Mitsuhashi N \& Mizuno M. In vivo effect of pituitary adenylate cyclase activating polypeptide 38 (PACAP 38) on the secretion of luteinizing hormone (LH) in male rats. Endocrinologia Japonica 199239 153-156.
39 Sawangjaroen K \& Curlewis JD. Effects of pituitary adenylate cyclase-activating polypeptide (PACAP) and vasoactive intestinal polypeptide (VIP) on prolactin, luteinizing hormone and growth hormone secretion in the ewe. Journal of Neuroendocrinology 1994 $6549-555$.

Received 14 July 1998

Accepted 24 November 1998 